\title{
Clone $\times$ Environment Interactions for Yellow-flesh Intensity in Tetraploid Potatoes
}

\author{
Kathleen G. Haynes \\ United States Department of Agriculture, Agricultural Research Service, 10300 Baltimore Avenue, \\ Building 010A, BARC-West, Beltsville, MD 20705 \\ Joseph B. Sieczka \\ Cornell University, Long Island Horticultural Research Laboratory, Riverhead, New York 11901
}

Melvin R. Henninger

Rutgers University, New Brunswick, New Jersey 08903

Diane L. Fleck

United States Department of Agriculture, Agricultural Research Service, Beltsville, MD 20705

Additional index words. Solanum tuberosum, broad-sense heritability, stability

\begin{abstract}
For the yellow-flesh fresh market, potato (Solanum tuberosum L.) cultivars with intense yellow-flesh are desired. The effects of clone, environment and clone $\times$ environment interactions on the intensity of the yellow-flesh trait in tetraploid potatoes were investigated. Twenty-four yellow-flesh clones, including 23 USDA selections and the check cultivar Yukon Gold, were evaluated for tuber yellow-flesh color as measured by a reflectance colorimeter in replicated field trials in Presque Isle, Maine in 1991 and 1992, and in Riverhead, N.Y., and Bridgeton, N.J., in 1992 and 1993. There were significant differences among environments and among clones for yellow-flesh intensity. The clone $\times$ environment interaction was also significant. Broad-sense heritability of yellow-flesh intensity was estimated as 0.93 with a $95 \%$ confidence interval of $\mathbf{0 . 9 2 - 0 . 9 7}$. The instabilities noted in some of these clones, although statistically significant, are of limited practical concern. The intensity of yellow-flesh will be an important trait for breeders to select in developing new yellow-flesh cultivars. However, in testing yellow-flesh clones for future cultivar release, the role of environment and clone $\times$ environment interactions on other agronomic traits will probably be more important than the environment and clone $\times$ environment interactions on the intensity of yellow-flesh.
\end{abstract}

'Yukon Gold', developed and released by Agriculture Canada (Johnston and Rowberry, 1981), is the first yellow-flesh potato cultivar to be widely accepted in the United States, and its success has led to renewed efforts in U.S. potato breeding programs to develop new, improved yellow-flesh cultivars (Haynes et al., 1994). The yellow-flesh trait is thought to be controlled by a single gene, with yellow dominant to white (Fruwirth, 1912; Simmonds, 1964). The variability in the intensity of yellow-flesh that exists in segregating populations has been explained by modifying genes (Black, 1930; Engel, 1957; Schick, 1956). Iwanzik et al. (1983) reported that clones differed greatly in their concentration of colorimparting carotenoids and that the contributions of individual carotenoids to yellow-flesh color were similar.

Nongenetic factors have also been shown to be involved in the expression of yellow-flesh intensity. Recently, Haynes et al. (1994) reported that tuber size, as measured by weight, was negatively correlated with yellow-flesh intensity. They measured the yellowflesh intensity for every tuber harvested from their plots for 2 years and found that a subsample of the $25-75$ percentile based on tuber weights was as informative as the full sample for average yellowflesh intensity and consistency of pairwise comparisons between individual selections and 'Yukon Gold'. This subsampling reduced the negative overall correlation coefficients between tuber weight and yellow-flesh intensity, but did not eliminate it.

Received for publication 29 June 1995. Accepted for publication 7 Nov. 1995. Mention of a trademark, warranty, proprietary product, or vendor does not constitute a guarantee by the U.S. Dept. of Agriculture and does not imply its approval to the exclusion of other products or vendors that may also be suitable. The cost of publishing this paper was defrayed in part by the payment of page charges. Under postal regulations, this paper therefore must be hereby marked advertisement solely to indicate this fact.
In evaluating yellow-flesh potato selections from a breeding program, consistent intensity of yellow-flesh across different growing environments would seem to be required for any potential new cultivar. However, research on the intensity of yellow-flesh across environments has not been reported. Clone $\times$ environment interactions are important sources of variation for many polygenic traits in potatoes, such as specific gravity (Haynes et al., 1995). For a predominantly monogenic trait such as yellow-flesh, which has been mapped to the third chromosome (Bonierbale et al., 1988) the magnitude of such interactions is unknown. Where these interactions account for a substantial portion of the observed variability, stability analysis (Shukla, 1972) is a very useful tool for partitioning the observed clone $\times$ environment variability among individual clones in the evaluated population. Clones which contribute relatively little to the overall clone $\times$ environment variation are more stable than clones which make a larger contribution.

The purposes of this study were 1) to evaluate the yellow-flesh intensity of 'Yukon Gold' and 23 yellow-flesh selections (clones) out of the USDA (Beltsville, Md.) potato breeding program in three different locations over two years (six environments), 2) to estimate the relative importance of clone $\times$ environment interactions on yellow-flesh intensity, 3) to estimate broad-sense heritability for yellow-flesh intensity, and 4) to determine the stability of yellow-flesh intensity.

\section{Materials and Methods}

Twenty-three advanced yellow-flesh selections from the USDA Beltsville, potato breeding program and the check cultivar 'Yukon Gold' (clones) were planted in Presque Isle, Maine, in 1991 and 1992 and in Riverhead, N.Y., and Bridgeton, N.J., in 1992 and 
1993. Seed tubers for clones tested at all locations were produced in Presque Isle. The experimental design was a randomized complete block with three replications. Plots consisted of five plants per clone, spaced 23 or $30 \mathrm{~cm}$ apart, in rows spaced 86 or $91 \mathrm{~cm}$ apart depending on location.

In 1991 and 1992 the experiments were planted at the Echo Lake Farm, Presque Isle, on a Caribou gravelly loam soil. In 1991 the experiment was planted 15 May and harvested 5 Oct. In 1992 the experiment was planted 18 May and harvested 7 Oct. In 1992 and 1993 the experiments were planted at Riverhead, New York and Bridgeton, New Jersey on a Haven silt loam and Sandy loam soil, respectively. In 1992 the experiment was planted 7 and 8 Apr., and harvested 4-5 Oct. and 11 Aug. in New York and New Jersey, respectively. In 1993 the experiment was planted 14 and $20 \mathrm{Apr}$., and harvested 14 Oct. and 17 Aug. in New York and New Jersey, respectively.

Tubers were dug with a single-row digger, picked up by hand and stored at $4 \mathrm{C}, 95 \%$ relative humidity in heavy paper bags until evaluated for yellow-flesh intensity. Tubers from New Jersey were evaluated during November and December, from New York during December and January, and from Maine during January and February. Yellow-flesh intensity was determined by a colorimeter (Colorgard System 1000; Byk-Gardner, Silver Spring, Md.) programmed to calculate a yellowness index (YI E-313) from two scales (American Society for Testing Materials, 1991). Tubers were removed from cold storage during the winter, sliced in half, patted dry on a paper towel, and each half was evaluated for yellow-flesh intensity on the colorimeter.

An analysis of variance was computed using the SAS (SAS Institute, Cary, N.C.) procedure GLM for the combined environments on the average yellow-flesh intensity per block. Mean squares from this analysis were used to estimate the clone, environment, and clone $\times$ environment components of variance. Broadsense heritability on a clonal mean basis was calculated as

$\mathrm{H}=\sigma_{\mathrm{C}}^{2} d\left(\sigma_{\mathrm{C}}^{2}+\sigma_{\mathrm{CE}}^{2} / \mathrm{e}+\sigma_{\mathrm{e}}^{2} / \mathrm{re}\right)$

where $\sigma_{\mathrm{C}}^{2}=$ clone variance, $\sigma_{\mathrm{CE}}^{2}=$ clone $\times$ environment variance, $\sigma^{2}{ }_{e}=$ error variance, $r=$ number of replications, and $e=$ number of environments.

Knapp et al. (1985) have calculated an exact confidence interval for $\mathrm{H}$. The upper confidence limit for $\mathrm{H}$ is

$1-\left[\left(\mathrm{MS}_{1} / \mathrm{MS}_{2}\right) \mathrm{F}_{(1-\alpha / 2: \mathrm{df} 2, \mathrm{df} 1)}\right]^{-1}$

The lower confidence limit for $\mathrm{H}$ is

$1-\left[\left(\mathrm{MS}_{1} / \mathrm{MS}_{2}\right) \mathrm{F}_{(\alpha / 2: \mathrm{df} 2, \mathrm{df} 1)}\right]^{-1}$

where $\mathrm{MS}_{1}=$ mean squares for clone and $\mathrm{MS}_{2}=$ mean squares for clone $\times$ environment.

The clone $\times$ environment interaction was partitioned into stability variance components $\left(\sigma^{2}\right)$ assignable to each clone (Shukla, 1972), using PROC IML in SAS (Kang, 1989). An environmental index was calculated as the average yellow-flesh intensity of all clones over all six environments minus the average yellow-flesh intensity of all clones in each environment. Heterogeneity, or nonadditivity, due to this environmental index was removed from the clone $\times$ environment interaction, and the remainder of the clone $\times$ environment interaction was partitioned into $s_{i}^{2}$ components assignable to each clone (Kang, 1989). Heterogeneity was expressed as a percent of the total clone $\times$ environment sums of squares.

\section{Results and Discussion}

The 1991 growing season in Maine was dry and hot from June through mid-August. In contrast, the 1992 growing season in Maine, New York, and New Jersey was cool with adequate moisture. The 1993 growing season in New York was hot and dry, with irrigation applied weekly beginning in mid-July. In New Jersey, early growth through May and June of 1993 was good, but July was very hot and dry, and irrigation was applied when needed.

There were significant differences among the environments and replications within environments on yellow-flesh intensity as measured by the YI E-313 index (Table 1). Environmental mean YI E-313 was highest in New Jersey for 1993 (55.7), followed by New Jersey in 1992 (54.4), New York in 1992 (54.0), Maine in 1991 (53.6), New York in 1993 (52.9), and Maine in 1992 (51.9) (Table 2). In 1992, clones were evaluated at all three locations, and there was a general trend of decreasing yellow-flesh intensity from south to north.

There were also significant differences among clones; and the clone $\times$ environment interaction was significant. From the analysis of variance, the estimate of broad-sense heritability for yellowflesh intensity on a clonal mean basis was 0.93 with a $95 \%$ confidence interval of 0.92-0.97. Most of the variation for yellowflesh intensity was accounted for by clonal variation. In spite of the significant clone $\times$ environment interaction, this interaction accounted for a very small proportion of the total variation. The six growing environments represented in this study ranged from cool and moist to hot and dry. Thus, they represented a wide range of conditions one might expect to encounter in the northeastern United States

Heterogeneity due to the environmental index was significant (Table 1). The environmental index accounted for $84 \%$ of the total clone $\times$ environment sum of squares.

The partitioning of the clone $\times$ environment sum of squares into $\sigma^{2}$ components (before removal of environmental heterogeneity) indicated that 20 of the 24 clones were unstable for yellow-flesh intensity (Table 2). When the linear effect of the environmental index was removed $\left(\mathrm{s}_{\mathrm{i}}^{2}\right)$, only three of the previously unstable clones were judged to be stable. Thus, the majority of the clones tested were judged to be unstable for yellow-flesh intensity before and after removing environmental heterogeneity. However, 'Yukon Gold' was judged to be stable across environments. Stability in this context is defined as the performance of a clone across environments being similar to the average performance of all clones across environments: a stable clone would have its highest yellow-flesh intensity in the environment where the average yellow-flesh intensity of all clones was highest, and its lowest yellow-flesh intensity

Table 1. Analysis of variance on the YI E-313 index for 24 yellow-flesh potato clones evaluated for 2 years in Presque Isle, Maine, Riverhead, N.Y., and Bridgeton, N.J.

\begin{tabular}{lrc}
\hline \hline Source & df & \multicolumn{1}{c}{ MS } \\
\hline Environments & 5 & $118.63^{* * *}$ \\
Replicates (environment) & 12 & $7.12^{* *}$ \\
Clones & 23 & $111.44^{* *}$ \\
Clone $(C) \times$ environment $(\mathrm{E})$ & 115 & $7.37^{* * *}$ \\
$\quad$ Heterogeneity & 23 & $30.90^{* *}$ \\
$\quad$ Residual C $\times$ E & 92 & 1.48 \\
Error & 275 & 2.07 \\
Total & 430 & \\
\hline
\end{tabular}

${ }^{* *}$ Significant at $P=0.01$. 
Table 2. Mean YIE-313 index of all harvested tubers from yellow-flesh potato clones evaluated in 1991 and 1992 in Presque Isle, Maine, and in 1992 and 1993 in Riverhead, N.Y., and Bridgeton, N.J., and the stability before $\left(\sigma_{i}^{2}\right)$ and after $\left(\mathrm{s}_{\mathrm{i}}^{2}\right)$ removing environmental heterogeneity.

\begin{tabular}{|c|c|c|c|c|c|c|c|c|c|}
\hline \multirow[b]{3}{*}{ Clone } & \multicolumn{6}{|c|}{ YI E-313 intensity } & \multirow[b]{3}{*}{ Mean } & \multirow[b]{3}{*}{$\sigma_{i}^{2}$} & \multirow[b]{3}{*}{$\mathrm{s}_{i}^{2}$} \\
\hline & \multicolumn{2}{|c|}{ Maine } & \multicolumn{2}{|c|}{ New York } & \multicolumn{2}{|c|}{ New Jersey } & & & \\
\hline & 1991 & 1992 & 1992 & 1993 & 1992 & 1993 & & & \\
\hline$\overline{\mathrm{B} 0180-24}$ & 54.1 & 53.2 & 53.5 & 54.1 & 54.5 & 59.9 & 54.9 & $8.5^{* *}$ & $8.5^{* *}$ \\
\hline B0806-13 & 46.6 & 46.3 & 49.4 & 46.5 & 51.1 & 49.7 & 48.3 & $5.7^{* * *}$ & $7.0^{* * *}$ \\
\hline B0808-11 & 48.3 & 47.3 & 49.3 & 49.6 & 50.7 & 53.9 & 49.8 & $4.9^{* *}$ & $3.8^{* * *}$ \\
\hline В0808-3 & 51.9 & 53.8 & 55.9 & 52.7 & 50.7 & 51.2 & 52.7 & $24.3^{* *}$ & $11.7^{* *}$ \\
\hline B0808-4 & 52.8 & 54.5 & 54.9 & 53.4 & 50.8 & 52.0 & 53.1 & $20.8^{* *}$ & $5.8^{* *}$ \\
\hline В0809-10 & 52.3 & 48.3 & 51.6 & 49.1 & 52.3 & 55.1 & 51.5 & $4.8^{* * *}$ & 1.3 \\
\hline B0809-2 & 53.3 & 52.3 & 52.2 & 51.3 & 53.6 & 52.3 & 52.5 & $5.4^{* *}$ & 2.3 \\
\hline B0809-3 & 52.3 & 51.3 & 53.6 & 50.5 & 51.0 & 53.2 & 52.0 & $4.3^{* * *}$ & $4.1^{* *}$ \\
\hline B0809-7 & 53.1 & 52.2 & 53.0 & 53.0 & 54.1 & 56.0 & 53.6 & 0.5 & 0.8 \\
\hline B0810-1 & 47.9 & 50.4 & 51.4 & 48.9 & 53.2 & 52.1 & 50.6 & $9.2^{* *}$ & $11.4^{* *}$ \\
\hline B0810-4 & 53.6 & 54.5 & 58.0 & 55.9 & 58.4 & 56.1 & 56.1 & $9.9^{* *}$ & $11.6^{* *}$ \\
\hline B0810-7 & 55.0 & 53.5 & 54.3 & 51.4 & 54.8 & 54.4 & 53.9 & $5.2^{* *}$ & $5.1^{* * *}$ \\
\hline B0811-13 & 56.4 & 52.0 & 53.2 & 53.8 & 54.5 & 58.0 & 54.7 & $5.8^{* * *}$ & $6.4^{* *}$ \\
\hline B0811-2 & 54.8 & 51.4 & 54.6 & 52.9 & 52.3 & 57.0 & 53.8 & $4.9^{* * *}$ & $5.8^{* *}$ \\
\hline B0811-4 & 58.1 & 53.8 & 57.1 & 57.4 & 56.8 & 60.5 & 57.3 & $4.5^{* *}$ & $4.4^{* *}$ \\
\hline B0813-11 & 54.1 & 48.3 & 53.6 & 53.2 & 56.0 & 55.8 & 53.5 & $9.9^{* *}$ & $7.1^{* *}$ \\
\hline B0813-14 & 57.8 & 52.8 & 56.7 & 58.0 & 59.2 & 61.8 & 57.7 & $11.1^{* *}$ & $5.9^{* * *}$ \\
\hline B0813-17 & 59.7 & 58.5 & 60.0 & 56.7 & 57.1 & 61.4 & 58.8 & $7.3^{* *}$ & $9.0^{* * *}$ \\
\hline B0813-2 & 50.1 & 48.7 & 53.0 & 53.9 & 55.0 & 54.9 & 52.6 & $11.4^{* * *}$ & $12.7^{* *}$ \\
\hline B0813-3 & 55.4 & 51.8 & 53.2 & 52.0 & 54.0 & 55.8 & 53.7 & 2.7 & $3.5^{* *}$ \\
\hline B0813-4 & 58.6 & 55.9 & 54.7 & 55.0 & 57.9 & 58.1 & 56.7 & $7.1^{* *}$ & $8.4^{* *}$ \\
\hline B0813-5 & 51.6 & 50.5 & 53.3 & 52.2 & 55.2 & 55.3 & 53.0 & 2.7 & 2.7 \\
\hline B0813-7 & 56.2 & 54.5 & 54.4 & 55.9 & 56.6 & 56.0 & 55.6 & $4.2^{* *}$ & 2.4 \\
\hline Yukon Gold & 53.7 & 50.2 & 54.4 & 52.5 & 55.5 & 56.6 & 53.8 & 3.1 & 0.5 \\
\hline Environmental mean & 53.6 & 51.9 & 54.0 & 52.9 & 54.4 & 55.7 & & & \\
\hline
\end{tabular}

${ }^{*, * * *}$ Significant at $P=0.05$ or 0.01 , respectively.

in the environment where the average yellow-flesh intensity of all clones was lowest.

Yellow-flesh color was more intense in many of the other clones tested than in 'Yukon Gold'. Another useful criteria in evaluating clones for yellow-flesh intensity would be to look for those with a more intense yellow-flesh and with less fluctuations across environments than 'Yukon Gold'. For example, in 'Yukon Gold' the difference between YI E-313 at the highest site (New Jersey, 1993) and at the lowest site (Maine, 1992) was 6.4. Clones with a higher average YI E-313 and a smaller range between highest and lowest sites were B0810-4, B0810-7, B0811-13, B0813-17, B0813-4, and B0813-7.

In spite of instabilities and clone $\times$ environment interactions on the intensity of yellow-flesh, the high heritability suggests that once an intense yellow-flesh clone is identified, it can be grown in multiple locations and retain its intense yellow-flesh. A clone with a yellow-flesh intensity at least equal to 'Yukon Gold', combined with other favorable agronomic characteristics, such as yield, shape, size, smoothness, freedom from defects, et cetera, would be an ideal candidate for naming and release. Indeed, once a clone with a desirable level of yellow-flesh intensity is produced, the clone $\times$ environment interactions on the other agronomic traits will probably be more important in determining its acceptability than any clone $\times$ environment interaction on yellow-flesh intensity.

\section{Literature Cited}

American Society for Testing Materials. 1991. ASTM standards on color and appearance measurement. 3rd ed. ASTM, Philadelphia. p. 239-242. Black, W. 1930. Notes on the progenies of various potato hybrids. J.
Genet. 22:27-43.

Bonierbale, M.W., R.L. Plaisted, and S.D. Tanksley. 1988. RFLP maps based on a common set of clones reveal modes of chromosomal evolution in potato and tomato. Genetics 120:1095-1103.

Engel, K.H. 1957. Grunlegende Fragen zu einem schema fur arbeiten mit inzuchten bei Kartoffeln. Zuchter 27:98-124.

Fruwirth, C. 1912. Zur Zuchtung der Kartoffel. Dtsch. Landw. Presse 39:551-552, 565-567.

Haynes, K.G., W.E. Potts, J.L. Chittams, and D.L. Fleck. 1994. Determining yellow-flesh intensity in potatoes. J. Amer. Soc. Hort. Sci. 119:10571059.

Haynes, K.G., D.R. Wilson, and M.S. Kang. 1995. Genotype $\times$ environment interactions for specific gravity in diploid potatoes. Crop Sci. 35:977-981.

Iwanzik, W., M. Tevini, R. Stute, and R. Hilbert. 1983. Carotinoidgehalt und-zusammensetzung verschiedener deutscher Kartoffelsorten und deren Bedeutung fur die Fleischfarbe der Knolle. Potato Res. 26:149162.

Johnston, G.R. and R.G. Rowberry. 1981. Yukon Gold: a new yellowfleshed, medium-early, high quality table and French-fry cultivar. Amer. Potato J. 58:241-244.

Kang, M.S. 1989. A new SAS program for calculating stability-variance parameters. J. Hered. 80:415.

Knapp, S.J., W.W. Stroup, and W.M. Ross. 1985. Exact confidence intervals for heritability on a progeny mean basis. Crop Sci. 25:192-194.

Schick, R. 1956. Methoden und Probleme der Kartoffelzuchtung. Zber. dtsch. Akad. LandWiss. Berl. 5(29):1-40.

Shukla, G.K. 1972. Some statistical aspects of partitioning genotypeenvironment components of variability. Heredity 29:237-245.

Simmonds, N.W. 1964. The genetics of seed tuber dormancy in the cultivated potatoes. Heredity 19:489-504. 